\title{
Renaissance and Reformation
}

Renaissance et Réforme

\section{Acciarino, Damiano. Lettere sulle grottesche (1580-1581)}

\section{Marco Piana}

Volume 42, numéro 1, winter 2019

URI : https://id.erudit.org/iderudit/1064535ar

DOI : https://doi.org/10.7202/1064535ar

Aller au sommaire du numéro

Éditeur(s)

Iter Press

ISSN

0034-429X (imprimé)

2293-7374 (numérique)

Découvrir la revue

Citer ce compte rendu

Piana, M. (2019). Compte rendu de [Acciarino, Damiano. Lettere sulle grottesche (1580-1581)]. Renaissance and Reformation / Renaissance et Réforme, 42(1), 365-367. https://doi.org/10.7202/1064535ar

All Rights Reserved @ Canadian Society for Renaissance Studies / Société canadienne d'études de la Renaissance, Pacific Northwest Renaissance Society, Toronto Renaissance and Reformation Colloquium and Victoria University Centre for Renaissance and Reformation Studies, 2019
Ce document est protégé par la loi sur le droit d'auteur. L'utilisation des services d'Érudit (y compris la reproduction) est assujettie à sa politique d'utilisation que vous pouvez consulter en ligne.

https://apropos.erudit.org/fr/usagers/politique-dutilisation/ 


\section{Book Reviews / Comptes Rendus}

\section{Acciarino, Damiano.}

\section{Lettere sulle grottesche (1580-1581).}

Collezione di Storia dell'arte moderna 2. Rome: Aracne, 2018. Pp. 168. ISBN 978-88-255-0725-6 (paperback) €18.

The word "grotesque"-which is now part of our everyday languageoriginated in the Italian Renaissance. The term was originally a noun defining an extravagant style of decorative art found in ancient Roman ruins, unearthed in the fifteenth century and commonly called grotte (caves) by the populace. Among these "caves" we find the rooms and corridors of Emperor Nero's Domus Aurea, the unfinished palace complex started after the Great Fire of Rome in $\mathrm{AD}$ 64, which had become overgrown and buried over the ages. Inside these newly discovered ruins, artists like Raffaello, Pinturicchio, and Signorelli found a new source of inspiration: a series of mysterious images of monstrosities, sensual mythologies, alchemical symbols, and Egyptian hieroglyphs. Imbued with such a striking form of alterity, these artists brought to the sources a new style of painting, reminiscent of antiquity and yet very well anchored in early modern iconography.

Since the outstanding work done by Paola Barocchi in compiling a corpus of sixteenth-century Italian texts on the visual arts, the Renaissance debate on the paintings known as grotesques has become increasingly important in the contemporary academic inquiry. This is due mostly to the multiplicity of academic aspects that are involved in it. Such paintings, as Dorothea Scholl well underlines in her preface, were the object of controversies that concerned not only the context of aesthetics and the visual arts, but also the domains of poetry, theology, and natural philosophy. The debate on the grotesque, moreover, became quickly involved with the major debate on images generated by the Reformation and the Counter-Reformation. Just like other artistic genres in contact with non-Christian antiquity, the grotesques progressively became the symbols of a culture of hybridity and decadence that needed to be purged from the Christian world.

Acciarino's work on this subject is quite remarkable, as it unveils crucial aspects of the post-Tridentine development of such a debate. Acciarino's selection of letters in the vernacular from the years 1580 to 1581 reveals the 
manifold complexity of the phenomenon of the grotesques in Renaissance Italy, especially in light of the deliberations of the Council of Trent. Divided between an apologetic stance reminiscent of Agostino Steuco's philosophia perenniswhere the grotesques and other forms of art reminiscent of the pagan world are seen as symbols and archetypes in line with Christian revelation-and a censorial perspective that saw the grotesques as degenerate and heretical works of art, capable of inducing in their viewers an alleged state of Dionysian hallucination, the Renaissance world represents the plurality of opinions on the issue of the Ancients: their knowledge, their art, their costumes.

What Acciarino provides in this work, however, is not just an outstanding collection of unedited materials, but a whole guide to the phenomenon of the grotesques in the late sixteenth century. In his lengthy introductory essay in Italian, Acciarino provides an excellent overview of the debate from which the letters originate. Together with a solid philological apparatus, Acciarino gives the reader the opportunity of getting acquainted with the opinions of some of the major players in the debate on images in post-Tridentine Italynamely, Gabriele Paleotti, Ulisse Aldrovandi, Pirro Ligorio, and Giambattista Bombelli-in order to better understand the relevance of the debate, and the importance of the letters chosen for the book.

Acciarino's selection of letters demonstrates the issue of situating the grotesques, a tribute to an Antiquity that went beyond the cliché of ideal beauty and white marbles, within a set of unstable paradigms of the ancient world typical of the Renaissance. Of particular relevance is Ulisse Aldrovandi's attempt to apply an etymological analysis to the term grottesche, spanning from Latin to ancient Greek and Hebrew, while another fascinating aspect of Aldrovandi's letters to Paleotti is the belief that images could have thaumaturgic qualities apt to cure fever and help the conception of healthy and good-looking children. Aldrovandi's perspective on the visual arts, somehow reminiscent of the Neoplatonic debate on beauty and practical magic, is a clear indicator of how certain forms of popular belief permeated all levels of society and were an essential aspect of the dispute over images of the late sixteenth century. Moreover, Aldrovandi brilliantly tackles the issue of monstrosity by reducing it to an aspect of nature, thus bringing the representation of the monstrous and imaginary into a realist and naturalist paradigm.

The letters of Pirro Ligorio and Giambattista Bombelli are not devoid of interesting perspectives. Ligorio's Neoplatonic attention to the world of 
symbols and metaphors shows how the Ficinian hermeneutic tradition was still relevant in the post-Tridentine humanist milieu, especially in those individuals who defended the grotesques and the ancient world from which they generated. Bombelli's relevance, on the other hand, is that of showing the counterapologetic side of the dispute. In Bombelli's letters, Aldrovandi's gracious ennoblement of the terms grotta and grottesche is reversed and plunged into an infernal vision of obscure prisons and pagan rituals dedicated to stygian deities. Similarly, Ligorio's attempted reductio ad symbola of the grotesques is harshly recanted, and the images in question are reduced to a disgusting excess of ancient and modern vanity.

Acciarino's edition of these precious unedited letters thus fills an essential gap in academic inquiry into the early modern debate on images and provides an invaluable set of sources to historians of art as well as historians of science and ideas.

MARCO PIANA

University of Toronto

\section{Bailey, Amanda, and Mario DiGangi, eds.}

\section{Affect Theory and Early Modern Texts: Politics, Ecologies, and Form.}

New York: Palgrave Macmillan, 2017. Pp. xi, 234. ISBN 978-1-137-57074-1 (hardcover) US\$99.99.

Affect studies have changed interpretations of early modern texts by considering different ways in which material, object-oriented, and socio-political culture and theory condition emotional and embodied agency. The scope of the functional relationship between the elements that shape the link between being and acting has been succinctly summarized by the editors of this timely, carefully assembled, and original collection of new essays: "In the past decade, new approaches to embodiment, power, and materialism have transformed our understanding of the relation between subjects and objects, agency and causation, the individual and the collective, and the somatic and the social" (1). This statement positions affect as a concept encompassing many facets of literature and culture that early criticism has addressed over several decades of scholarship. It suggests that affect can be understood to be at once specific and 